
\title{
$\begin{array}{ll}\text { Research Square } & \begin{array}{l}\text { Preprints are preliminary reports that have not undergone peer review. } \\ \text { They should not be considered conclusive, used to inform clinical practice, }\end{array} \\ \text { or referenced by the media as validated information. }\end{array}$
}

\section{Renin-angiotensin system inhibitors and severity of SARS-CoV-2 infection: a meta-analysis}

\section{Teodoro J. Oscanoa ( $\nabla$ tjoscanoae@gmail.com )}

1. Department of Pharmacology, Facultad de Medicina, Universidad Nacional Mayor de San Marcos.

Drug Safety Research Center, Facultad de Medicina Humana, Universidad de San Martín de Porres.

Hospital Almenara, ESSALUD, Lima, Perú. https://orcid.org/0000-0001-9379-4767

\section{Xavier Vidal}

Clinical Pharmacology Department, Valld'Hebrón Hospital, Barcelona, Spain https://orcid.org/00000001-6705-4298

\section{Alfonso Carvajal}

Centro de Estudios sobre la Seguridad de los Medicamentos (CESME), Universidad de Valladolid, Valladolid https://orcid.org/0000-0001-8224-695X

\section{Roman Romero-Ortuno}

Discipline of Medical Gerontology, Mercer's Institute for Successful Ageing, St James's Hospital, Dublin, Ireland. Global Brain Health Institute, Trinity College Dublin, Ireland https://orcid.org/0000-0002-38827447

\section{Systematic Review}

Keywords: SARS-CoV-2; COVID-19, Angiotensin II receptor blockers, Angiotensin-converting enzyme inhibitors, Renin-Angiotensin system (RAS).

Posted Date: May 21st, 2020

DOI: https://doi.org/10.21203/rs.3.rs-29483/v1

License: (c) (i) This work is licensed under a Creative Commons Attribution 4.0 International License. Read Full License 


\section{Abstract}

\section{Introduction}

The mechanism of entry of SARS-CoV-2 into the human host cell is through the ACE2 receptor. During the pandemic, a hypothesis has been proposed that Angiotensin-converting enzyme inhibitors (ACEi) and Angiotensin II receptor blockers (ARBs) could be risk factors for the development of severe SARS-CoV-2 infection.

\section{Objective}

To conduct a meta-analysis of the association between ACEi or ARB use and SARS-CoV-2 infection severity or mortality.

\section{Data Sources}

We searched PubMed, EMBASE, Google scholar and the Cochrane Database of Systematic Reviews for observational studies published between December 2019 and April 24, 2020

Study Selection: Studies were included if they contained data on ACEi or ARB use and SARS-CoV-2 infection severity or mortality. Effect statistics were pooled using random-effects models. The quality of included studies was assessed with the Newcastle-Ottawa Scale (NOS).

\section{Data Extraction}

Data on study design, study location, year of publication, study design, number of participants, sex, age at baseline, outcome definition, exposure definition, follow-up, effect estimates and 95\% Cis.

\section{Results}

Thirteen observational studies were identified for inclusion, combining to a total sample of 14364 participants. Mean age was 59.2 (SD 7.3) years and 53.5\% were men. Mean follow-up was 28.3 (14.2) days. The mean NOS score of included studies was 7.8 (range: 7-9). Results suggested that ACEi or ARB use did not increase the risk of severe disease or mortality from SARS-CoV- 2 infection $(\mathrm{OR}=0.72,95 \% \mathrm{Cl}$ $0.47-1.11, p=0.138)$.

\section{Conclusions}

At present, the limited evidence available does not support the hypothesis of increased SARS-CoV-2 risk with ACEi or ARB drugs. However, more evidence needs to accumulate before this controversy can be resolved. 


\section{Introduction}

It had not been anticipated that a phenomenon such as the appearance of the new SARS-CoV-2 pandemic would affect the world in such a short time and lead to serious health and economic consequences. Scientists around the world are in a race against time in the search for effective treatment approaches. Among the many questions that need urgent clarification is that of the possible drug-disease interactions in patients taking Angiotensin-converting enzyme inhibitors (ACEi) and Angiotensin II receptor blockers (ARBs). These are among the most widely used antihypertensive drug classes in the world [1].

The Renin-Angiotensin system (RAS) has the function of maintaining homeostasis of blood pressure, fluid and salt in the human body. RAS contains two homologous enzymes belonging to the Angiotensin converting enzyme (ACE) dipeptidyl carboxypeptidase family, with different functions: the Angiotensin I converting enzyme 1 (ACE1) converts Angiotensin I to Angiotensin II; and the Angiotensin I converting enzyme 2 (ACE2) decreases the level of Angiotensin II and negatively regulates the RAS system. Thus, ACE2 reduces the effects of vasoconstriction, sodium retention and fibrosis. ACE2 is expressed in various organs such as the heart, kidneys and especially in alveolar epithelial cells of the lung [2]. Under normal conditions, circulating levels of soluble ACE2 are low and its function at the lung level is minimal [3].

The mechanism of entry of SARS-CoV-2 into the human host cell is through the ACE2 receptor. SARSCoV-2 has an envelope made up of glycoproteins, called S1 (Spike) and S2, the former binding to ACE2 on the cell surface and the latter with the cell membrane[4]. While this mechanism is similar to that of another coronavirus that caused the SARS epidemic in 2002-2003 [5,6], SARS-CoV-2 has a higher affinity for ACE2 [7]. Although their three-dimensional structure is similar, SARS-CoV and SARS-CoV-2 differ in about $28 \%$ of the amino acid sequence in the receptor binding domains; SARS-CoV-2 has a distinct loop with flexible glycyl residues replacing rigid prolyl residues, which makes it structure less rigid and may explain its greater affinity for the ACE2 receptor [7].

ACE2 was involved in the pathophysiology of SARS-CoV infection [8] and it is feared that in SARS-CoV-2 infection, this effect could be of greater magnitude. In addition, prior to the pandemic it had been reported that ACEi/ARBs could increase mRNA expression of ACE2 at the cardiac level [9]. Hence, it has been hypothesized that ACEi and/or ARBs could be risk factors for the development of severe forms of SARSCoV-2 infection $[10,11]$ In the midst of the COVID-19 pandemic crisis, this simple hypothesis was, without clinical or research evidence to support it, widely disseminated by the media, which in turn caused great concern to patients who were taking these medications. Official statements rapidly followed recommending that these medications continue to be taken [12]in view of the absence of evidence to support the hypothesis. However, the absence of evidence does not mean evidence of absence and there is still an urgent need for clarification. In that light, we conducted a meta-analysis of the association between ACEi or ARB use and SARS-CoV-2 infection severity or mortality.

\section{Methods}


This study was conducted following the guidelines of the Preferred Reporting Items for Systematic Reviews and Meta-analyses (PRISMA)[13].

Search strategy

Two independent investigators performed a systematic search in PubMed, EMBASE, Google scholar and the Cochrane Database of Systematic Reviews for observational studies published between December 2019 and April 24, 2020. In addition, we conducted a secondary search based on the reference list of retrieved articles. The PubMed search strategy is detailed in Supplementary Table A.

Eligibility criteria

We searched for randomized controlled trials (RCTs) or observational studies reporting data on ACEi or ARB use and SARS-CoV-2 infection severity or mortality. We included studies in English or other languages (all ages) meeting the following criteria: a) COVID-19 patients were diagnosed according to the interim guidance of the World Health Organization [14]; b) the study presented data on hazard ratios (HRs), relative risks (RRs), or odds ratios (ORs) with confidence intervals (Cls) or offered enough data to allow these to be calculated (including via email correspondence with original authors if necessary); and c) SARS-CoV-2 infection severity criteria were described.

Quality assessment

The quality of observational studies (cohort and case-control studies) and RCTs were assessed according to the Newcastle-Ottawa Quality Assessment Scale (NOS) [15] and the Cochrane Risk of Bias Assessment Tool [16], respectively. Two investigators evaluated the quality of the studies independently. Conflicting results were resolved by discussion and involvement of a third reviewer if necessary.

Data extraction

The following data were extracted from each study: authors, study location, year of publication, study design, number of participants, sex, age at baseline, outcome definition, exposure definition, follow-up, effect estimates and $95 \%$ Cls.

Statistical analyses

Primary analyses evaluated the association (HRs, RRs or ORs) between use of ACEi or ARB and SARSCoV-2 infection severity or mortality. We used random effects with an inverse variance method to calculate the pooled RRs and $95 \% \mathrm{Cls}$ according to the heterogeneity between studies [17]. The overall estimates in the pooled analysis were obtained using using Stata 13 software (StataCorp LP, College Station, TX).

\section{Results}


After screening 343 citations, 13 observational studies were included (Figure 1) [18-30], combining to a total sample of 14,364 participants. The characteristics of included studies are summarized in Table 1. Ten studies were from China, with the other three being from UK, USA and Korea. Overall, mean age was 59.2 (SD 7.5) years and 53.5\% were men. Mean follow-up was 28.3 (14.2) days. The mean NOS score of included studies was 7.8 (range: 7-9). The outcomes reported in the included studies are presented in Table 1.

For the meta-analysis, we used the combined outcome of severe disease and/or mortality. As shown in Figure 2, the meta-analysis suggested that ACEi or ARB use did not increase the risk of severe disease or mortality from SARS-CoV-2 infection ( $\mathrm{OR}=0.72,95 \% \mathrm{Cl} 0.47-1.11, \mathrm{p}=0.138)$. Subgroup analyses were conducted to assess ACEi and ARB effects separately (Table 2) but no significant associations were found. Subgroup analyses were also negative for the effects of age ( $<60 v s .60+)$ or sex (Table 2 ).

\section{Discussion}

Our study found no evidence to support the hypothesis of increased SARS-CoV-2 risk with ACEi or ARB drugs. This would seem at odds with a previous finding that chronic use of ACEi and ARBs was high among intensive care unit patients with non-COVID-19 sepsis [31]. However, it is possible that ACEls/ARBs could be a marker of underlying comorbidities rather than being causal in SARS-CoV-2 severity or mortality.

Prior to the SARS-CoV-2 pandemic, Shinohara et al. published a meta-analytic study where they found a decreased risk of post-stroke pneumonia in patients treated with ACEi compared to other antihypertensive drugs (RR: $0.61,95 \% \mathrm{Cl} 0.51-0.75 ; \mathrm{P}<0.001$ ) [32]. In another meta-analysis, Liu et al. found that ARBs were associated with a decreased risk of pneumonia morbidity $(\mathrm{OR}=0.55,95 \% \mathrm{Cl} ; 0.43-0.70, \mathrm{p}<0.01)$ and mortality $(\mathrm{OR}=0.55,95 \% \mathrm{Cl} ; 0.44-0.69, \mathrm{p}<0.01)$ [21]. These findings could however be seen from the perspective that the prescription of ACEi/ARBs may be a marker of good general medical care, given the well-evidenced preventative role of these medications in many cardiovascular and metabolic diseases.

The basis for the hypothesis of a probable ACEi/ARB-induced increase in ACE2 expression has been recently revised, evaluating the results of 12 animal and 11 human studies [33]. In animal studies, no significant changes in ACE2 expression were found, and in those where it was evidenced, it was when models of acute injury were used or at higher doses than those used in humans; furthermore, no increase in ACE2 expression induced by ACEi/ARBs was evidenced in human studies [33].

It has been proposed that ARBs may have protective effects on severity and mortality in SARS-CoV-2 infection through increasing the production of Angiotensin 1-7, reducing Angiotensin II and contributing towards lung protection [34]. Recently, Liu et al. found that Angiotensin II levels in the plasma of COVID19 infected patients was markedly elevated and linearly associated to viral load and lung injury [35]. However, this may be a marker of general physiological stress during severe acute illness and not have specific drug-disease implications. 
Our study is limited in that it only relies on observational studies and not RCTs and includes a relatively small number of participants. It would be important that future, more powered studies, re-evaluate the possible relevance of age (young vs. old), sex, and possible different roles of ACEi and ARB drugs. It would also be important to assess the risk of specific comorbidities (e.g. diabetes, hypertension, cerebrovascular disease, ischemic heart disease) in the absence of ACEi/ARB drugs. For example, Feng et al. showed that hypertension without ACEi/ARB therapy was an independent risk factor for developing severe pneumonia irrespective of age[20].

In conclusion, the limited evidence available at present does not support the hypothesis of increased SARS-CoV-2 risk with ACEi or ARB drugs. However, more evidence needs to accumulate before this controversy can be resolved; in the meantime, clinicians may adopt a tailored, pragmatic approach that is supported by official recommendations $[12,35]$.

\section{Declarations}

\section{Competing interests}

\begin{tabular}{ll} 
Author & Competing interests \\
\hline Teodoro J. Oscanoa & declare no competing interests \\
\hline Xavier Vidal & declare no competing interests \\
\hline Alfonso Carvajal & declare no competing interests \\
\hline Roman Romero-Ortuno & declare no competing interests
\end{tabular}

\section{References}

1. Derington CG, King JB, Herrick JS, Shimbo D, Kronish IM, Saseen JJ, et al. Trends in Antihypertensive Medication Monotherapy and Combination Use Among US Adults, National Health and Nutrition Examination Survey 2005-2016. Hypertension [Internet]. 2020;75:973-81. Available from: https://www.ahajournals.org/doi/10.1161/HYPERTENSIONAHA.119.14360

2. Hamming I, Timens W, Bulthuis M, Lely A, Navis G, van Goor H. Tissue distribution of ACE2 protein, the functional receptor for SARS coronavirus. A first step in understanding SARS pathogenesis. The Journal of Pathology [Internet]. 2004;203:631-7. Available from: http://doi.wiley.com/10.1002/path.1570

3. Serfozo P, Wysocki J, Gulua G, Schulze A, Ye M, Liu P, et al. Ang II (Angiotensin II) Conversion to Angiotensin-(1-7) in the Circulation Is POP (Prolyloligopeptidase)-Dependent and ACE2 (AngiotensinConverting Enzyme 2)-Independent. Hypertension [Internet]. 2020;75:173-82. Available from: https://www.ahajournals.org/doi/10.1161/HYPERTENSIONAHA.119.14071 
4. Zhou P, Yang X-L, Wang X-G, Hu B, Zhang L, Zhang W, et al. A pneumonia outbreak associated with a new coronavirus of probable bat origin. Nature [Internet]. 2020;579:270-3. Available from: http://www.nature.com/articles/s41586-020-2012-7

5. Ge X-Y, Li J-L, Yang X-L, Chmura AA, Zhu G, Epstein JH, et al. Isolation and characterization of a bat SARS-like coronavirus that uses the ACE2 receptor. Nature [Internet]. 2013;503:535-8. Available from: http://www.nature.com/articles/nature12711

6. Prabakaran P, Xiao X, Dimitrov DS. A model of the ACE2 structure and function as a SARS-CoV receptor. Biochemical and Biophysical Research Communications [Internet]. 2004;314:235-41. Available from: https://linkinghub.elsevier.com/retrieve/pii/S0006291X03026792

7. Cheng ZJ, Shan J. 2019 Novel coronavirus: where we are and what we know. Infection [Internet]. 2020;48:155-63. Available from: http://link.springer.com/10.1007/s15010-020-01401-y

8. de Wit E, van Doremalen N, Falzarano D, Munster VJ. SARS and MERS: recent insights into emerging coronaviruses. Nature Reviews Microbiology [Internet]. 2016;14:523-34. Available from: http://www.nature.com/articles/nrmicro.2016.81

9. Ferrario CM, Jessup J, Chappell MC, Averill DB, Brosnihan KB, Tallant EA, et al. Effect of AngiotensinConverting Enzyme Inhibition and Angiotensin II Receptor Blockers on Cardiac AngiotensinConverting Enzyme 2. Circulation [Internet]. 2005;111:2605-10. Available from: https://www.ahajournals.org/doi/10.1161/CIRCULATIONAHA.104.510461

10. Sommerstein R, Kochen MM, Messerli FH, Gräni C. Coronavirus Disease 2019 (COVID-19): Do Angiotensin-Converting Enzyme Inhibitors/Angiotensin Receptor Blockers Have a Biphasic Effect? Journal of the American Heart Association [Internet]. 2020;9. Available from: https://www.ahajournals.org/doi/10.1161/JAHA.120.016509

11. Fang L, Karakiulakis $G$, Roth M. Are patients with hypertension and diabetes mellitus at increased risk for COVID-19 infection? The Lancet Respiratory Medicine [Internet]. 2020;8:e21. Available from: https://linkinghub.elsevier.com/retrieve/pii/S2213260020301168

12. Bavishi C, Maddox TM, Messerli FH. Coronavirus Disease 2019 (COVID-19) Infection and Renin Angiotensin System Blockers. JAMA Cardiology [Internet]. 2020; Available from: https://jamanetwork.com/journals/jamacardiology/fullarticle/2764299

13. Moher D, Liberati A, Tetzlaff J, Altman DG. Preferred Reporting Items for Systematic Reviews and Meta-Analyses: The PRISMA Statement. PLoS Medicine [Internet]. 2009;6:e1000097. Available from: https://dx.plos.org/10.1371/journal.pmed.1000097

14. World Health Organization. Clinical management of severe acute respiratory infection when COVID19 is suspected. https://www.who.int/publications-detail/clinical-management-of-severe-acuterespiratory-infection-when-novel-coronavirus-(ncov)-infection-is-suspected. 2020;

15. Stang A. Critical evaluation of the Newcastle-Ottawa scale for the assessment of the quality of nonrandomized studies in meta-analyses. European Journal of Epidemiology [Internet]. 2010;25:603-5. Available from: http://link.springer.com/10.1007/s10654-010-9491-z 
16. Cumpston M, Li T, Page MJ, Chandler J, Welch VA, Higgins JP, et al. Updated guidance for trusted systematic reviews: a new edition of the Cochrane Handbook for Systematic Reviews of Interventions. Cochrane Database of Systematic Reviews [Internet]. 2019; Available from: http://doi.wiley.com/10.1002/14651858.ED000142

17. DerSimonian R, Laird N. Meta-analysis in clinical trials. Controlled Clinical Trials [Internet]. 1986;7:177-88. Available from: https://linkinghub.elsevier.com/retrieve/pii/0197245686900462

18. Guo T, Fan Y, Chen M, Wu X, Zhang L, He T, et al. Cardiovascular Implications of Fatal Outcomes of Patients With Coronavirus Disease 2019 (COVID-19). JAMA Cardiology [Internet]. 2020; Available from: https://jamanetwork.com/journals/jamacardiology/fullarticle/2763845

19. Meng J, Xiao G, Zhang J, He X, Ou M, Bi J, et al. Renin-angiotensin system inhibitors improve the clinical outcomes of COVID-19 patients with hypertension. Emerging Microbes \& Infections [Internet]. 2020;9:757-60. Available from: https://www.tandfonline.com/doi/full/10.1080/22221751.2020.1746200

20. Feng Z, Li J, Yao S, Yu Q, Zhou W, Mao; Xiaowen, et al. The Use of Adjuvant Therapy in Preventing Progression to Severe Pneumonia in Patients with Coronavirus Disease 2019: A Multicenter Data Analysis. Available from: https://doi.org/10.1101/2020.04.08.20057539

21. Liu Y, Huang F, Xu J, Yang P, Qin Y, Cao M, et al. Anti-hypertensive Angiotensin II receptor blockers associated to mitigation of disease severity in elderly COVID-19 patients doi: medRxiv preprint. Available from: https://doi.org/10.1101/2020.03.20.20039586

22. Yang G, Tan Z, Zhou L, Yang M, Peng L, Liu J, et al. Angiotensin II Receptor Blockers and AngiotensinConverting Enzyme Inhibitors Usage is Associated with Improved Inflammatory Status and Clinical Outcomes in COVID-19 Patients With Hypertension. Available from: https://doi.org/10.1101/2020.03.31.20038935

23. Feng Y, Ling Y, Bai T, Xie Y, Huang J, Li J, et al. COVID-19 with Different Severity: A Multi-center Study of Clinical Features. American Journal of Respiratory and Critical Care Medicine [Internet]. 2020;rccm.202002-04450C. Available from: https://www.atsjournals.org/doi/10.1164/rccm.202002$04450 \mathrm{C}$

24. Zhang P, Zhu L, Cai J, Lei F, Qin J-J, Xie J, et al. Association of Inpatient Use of Angiotensin Converting Enzyme Inhibitors and Angiotensin II Receptor Blockers with Mortality Among Patients With Hypertension Hospitalized With COVID-19. Circulation Research [Internet]. 2020;CIRCRESAHA.120.317134. Available from: https://www.ahajournals.org/doi/10.1161/CIRCRESAHA.120.317134

25. Lee H-Y, Ahn J, Kang CK, Won S-H, Park J-H, Kang CH, et al. Association of Angiotensin II Receptor Blockers and Angiotensin-Converting Enzyme Inhibitors on COVID-19-Related Outcome. SSRN Electronic Journal [Internet]. 2020; Available from: https://www.ssrn.com/abstract=3569837

26. Bean D, Kraljevic Z, Searle T, Bendayan R, Pickles A, Folarin A, et al. Treatment with ACE-inhibitors is not associated with early severe SARSCovid- 19 infection in a multi-site UK acute Hospital Trust. 
Available from: https://www.medrxiv.org/content/101101/2020040720056788v1.article-metrics. 2020;

27. Peng YD, Guan HQ, Leng L, Zhu RR, Wang BY, et al. . Clinical characteristics and outcomes of 112 cardiovascular disease patients infected by 2019-nCoV. Zhonghua Xin Xue Guan Bing Za Zhi 2020 Mar 2;48(0):E004 doi: 103760/cma.j.cn112148-20200220-00105. 2020;

28. Rentsch C, et al. Covid-19 Testing, Hospital Admission, and Intensive Care Among 2,026,227 United States 2 Veterans Aged 54-75 Years. MedRxiv 2020; Available from: https://doi.org/101101/2020040920059964.

29. Zeng Z, Zhang Y, Wu F, Hu H, Li H, et. al. Hypertension in patients hospitalized with COVID-19 in Wuhan, China: A single-center retrospective observational study. . MedRxiv 2020; Available from: https://doi.org/101101/2020040620054825.

30. Li J, Wang X, Chen J, Zhang H, Deng A. Association of Renin-Angiotensin System Inhibitors With Severity or Risk of Death in Patients With Hypertension Hospitalized for Coronavirus Disease 2019 (COVID-19) Infection in Wuhan, China. JAMA Cardiology [Internet]. 2020; Available from: https://jamanetwork.com/journals/jamacardiology/fullarticle/2765049

31. Sunden-Cullberg J. Chronic Use of Angiotensin-Converting Enzyme Inhibitors and Angiotensin II Receptor Blockers Is High Among Intensive Care Unit Patients With Non-COVID-19 Sepsis but Carry a Moderately Increased Risk of Death. Hypertension [Internet]. 2020; Available from: https://www.ahajournals.org/doi/10.1161/HYPERTENSIONAHA.120.15178

32. Shinohara Y, Origasa H. Post-Stroke Pneumonia Prevention by Angiotensin-Converting Enzyme Inhibitors: Results of a Meta-analysis of Five Studies in Asians. Advances in Therapy [Internet]. 2012;29:900-12. Available from: http://link.springer.com/10.1007/s12325-012-0049-1

33. Sriram K, Insel PA. Dangers of ACE inhibitor and ARB usage in COVID-19: evaluating the evidence. Available from: https://doi.org/10.1101/2020.03.25.20043927

34. Gurwitz D. Angiotensin receptor blockers as tentative SARS-CoV-2 therapeutics. Drug Development Research [Internet]. 2020;ddr.21656. Available from: https://onlinelibrary.wiley.com/doi/abs/10.1002/ddr.21656

35. Liu Y, Yang Y, Zhang C, Huang F, Wang F, Yuan J, et al. Clinical and biochemical indexes from 2019$\mathrm{nCoV}$ infected patients linked to viral loads and lung injury. Science China Life Sciences [Internet]. 2020;63:364-74. Available from: http://link.springer.com/10.1007/s11427-020-1643-8

\section{Tables}

Table 1. Characteristics of the 12 studies included in the meta-analysis. 


\begin{tabular}{|c|c|c|c|c|c|c|c|c|c|c|}
\hline $\begin{array}{l}\text { Study } \\
\text { (year) }\end{array}$ & Country & $\begin{array}{l}\text { Study } \\
\text { design }\end{array}$ & $\begin{array}{l}\text { Total } \\
\text { Sample } \\
\text { size }\end{array}$ & $\begin{array}{l}\text { Mean age } \\
\text { (SD) }\end{array}$ & $\begin{array}{l}\text { Male } \\
\text { sex } \\
(\%)\end{array}$ & $\begin{array}{l}\text { Follow- } \\
\text { up (SD) } \\
\text { days }\end{array}$ & $\begin{array}{l}\text { OR } \\
(95 \% \mathrm{CI})\end{array}$ & Outcome & $\begin{array}{l}\text { Type of } \\
\text { RAS } \\
\text { inhibitor }\end{array}$ & NOS \\
\hline $\begin{array}{l}\text { Guo T et } \\
\text { al. (2020) }\end{array}$ & China & $\mathrm{CC}$ & 187 & $58.5(14.7)$ & 48.7 & $\begin{array}{l}26.3 \\
(9.0)\end{array}$ & $\begin{array}{l}1.70(0.63- \\
4.58)\end{array}$ & Mortality & ACEi/ARB & 8 \\
\hline \multirow[t]{2}{*}{$\begin{array}{l}\text { Liu Y et al. } \\
(2020)\end{array}$} & \multirow[t]{2}{*}{ China } & \multirow[t]{2}{*}{$\mathrm{CC}$} & \multirow[t]{2}{*}{511} & \multirow[t]{2}{*}{$>65$} & \multirow[t]{2}{*}{55.1} & \multirow[t]{2}{*}{ No data } & $\begin{array}{l}0.34(0.13- \\
0.92)\end{array}$ & Severe disease & ARB & \multirow[t]{2}{*}{8} \\
\hline & & & & & & & $\begin{array}{l}0.57(0.14- \\
2.34)\end{array}$ & Severe disease & ACEi & \\
\hline $\begin{array}{l}\text { Peng Y et } \\
\text { al. (2020) }\end{array}$ & China & $\mathrm{CC}$ & 112 & 62.0 & 47.3 & No data & $\begin{array}{l}1.32(0.38- \\
4.52)\end{array}$ & Mortality & ACEi/ARB & 8 \\
\hline $\begin{array}{l}\text { Meng J et } \\
\text { al. (2020) }\end{array}$ & China & $\mathrm{CC}$ & 417 & 64.5 & 57.1 & 20 & $\begin{array}{l}0.33(0.09- \\
1.31)\end{array}$ & Severity/mortality & ACEi/ARB & 8 \\
\hline \multirow[t]{2}{*}{$\begin{array}{l}\text { Bean D et } \\
\text { al. (2020) }\end{array}$} & \multirow[t]{2}{*}{ UK } & \multirow[t]{2}{*}{$\mathrm{CC}$} & \multirow[t]{2}{*}{205} & \multirow[t]{2}{*}{63.0} & \multirow[t]{2}{*}{51.7} & \multirow[t]{2}{*}{7} & $\begin{array}{l}0.29(0.1- \\
0.75)\end{array}$ & $\begin{array}{l}\text { Mortality/ required } \\
\text { critical care }\end{array}$ & ACEi & \multirow[t]{2}{*}{7} \\
\hline & & & & & & & $\begin{array}{l}2.4(0.62- \\
9.30)\end{array}$ & $\begin{array}{l}\text { Mortality/ required } \\
\text { critical care }\end{array}$ & ARB & \\
\hline \multirow[t]{2}{*}{$\begin{array}{l}\text { Yang G et } \\
\text { al. (2020) }\end{array}$} & \multirow[t]{2}{*}{ China } & \multirow[t]{2}{*}{$\mathrm{CC}$} & \multirow[t]{2}{*}{462} & \multirow[t]{2}{*}{67} & \multirow[t]{2}{*}{49.4} & \multirow[t]{2}{*}{$\begin{array}{l}35.2 \\
(12.8)\end{array}$} & $\begin{array}{l}0.32(0.07- \\
1.51)\end{array}$ & Mortality & \multirow[t]{2}{*}{$\mathrm{ACEi} / \mathrm{ARB}$} & \multirow[t]{2}{*}{9} \\
\hline & & & & & & & $\begin{array}{l}0.3455 \\
(0.11-1.10)\end{array}$ & $\begin{array}{l}\text { Critical vs. } \\
\text { noncritical }\end{array}$ & & \\
\hline \multirow[t]{3}{*}{$\begin{array}{l}\text { Feng Y et } \\
\text { al. (2020) }\end{array}$} & \multirow[t]{3}{*}{ China } & \multirow[t]{3}{*}{$\mathrm{CC}$} & \multirow[t]{3}{*}{476} & \multirow{3}{*}{$\begin{array}{l}\text { Median } \\
\text { (IQR) } 53 \text { (40- } \\
64)\end{array}$} & \multirow[t]{3}{*}{56.9} & $\begin{array}{l}16 \\
\text { (range: }\end{array}$ & $\begin{array}{l}0.18(0.06- \\
0.57)\end{array}$ & $\begin{array}{l}\text { Severity (severe and } \\
\text { critical vs moderate) }\end{array}$ & ACEi/ARB & 8 \\
\hline & & & & & & & $\begin{array}{l}0.26 \\
(0.08-0.84) \\
\end{array}$ & $\begin{array}{l}\text { Severity (severe and } \\
\text { critical vs moderate }\end{array}$ & ARB & \\
\hline & & & & & & & $\begin{array}{l}0.27(0.03- \\
2.27)\end{array}$ & $\begin{array}{l}\text { Severity (severe and } \\
\text { critical vs moderate }\end{array}$ & $\mathrm{ACEi}$ & \\
\hline $\begin{array}{l}\text { Feng Z et } \\
\text { al. (2020) }\end{array}$ & China & $\mathrm{CC}$ & 564 & 47 (36-58) & 50.4 & No data & $\begin{array}{l}0.41(0.05- \\
3.19)\end{array}$ & Severe pneumonia & ACEi/ARB & 8 \\
\hline $\begin{array}{l}\text { Rentsch C. } \\
\text { et al }\end{array}$ & USA & CC & 585 & $\begin{array}{l}\text { Median } \\
\text { (IQR) } 66 \text { (60- }\end{array}$ & 95.4 & No data & $\begin{array}{l}1.66(0.94- \\
2.93)\end{array}$ & Intensive care & ACEi/ARB & 7 \\
\hline (2020) & & & & 71) & & & $\begin{array}{l}1.28(0.76- \\
2.16)\end{array}$ & & ARB & \\
\hline & & & & & & & $\begin{array}{l}2.01(1.32- \\
3.05)\end{array}$ & & $\mathrm{ACEi}$ & \\
\hline $\begin{array}{l}\text { Zeng Z et } \\
\text { al. (2020) }\end{array}$ & China & $\mathrm{CC}$ & 274 & 67 & 47 & $\begin{array}{l}20(14- \\
27)\end{array}$ & $\begin{array}{l}2.46(0.94- \\
6.40)\end{array}$ & $\begin{array}{l}\text { Severe vs non } \\
\text { severe pneumonia }\end{array}$ & ACEi/ARB & 8 \\
\hline & & & & & & & $\begin{array}{l}0.65(0.12- \\
3.58)\end{array}$ & Mortality & ACEi/ARB & \\
\hline $\begin{array}{l}\text { Lee } \mathrm{H} \text { et } \\
\text { al. (2020) }\end{array}$ & Korea & $\mathrm{CC}$ & 8266 & $44.4(19.1)$ & 38.5 & 60 & $\begin{array}{l}\mathrm{HR}=1.07 \\
(0.68-1.65)\end{array}$ & Mortality & ACEi/ARB & 7 \\
\hline & & & & & & & $\begin{array}{l}\mathrm{HR}=1.09 \\
(0.70-1.70)\end{array}$ & Mortality & ARB & \\
\hline & & & & & & & $\begin{array}{l}\mathrm{HR}=0.72 \\
(0.17-3.04)\end{array}$ & Mortality & $\mathrm{ACEi}$ & \\
\hline $\begin{array}{l}\text { Zhang P et } \\
\text { al. (2020) }\end{array}$ & China & CC & 1128 & $\begin{array}{l}\text { Median } \\
\text { (IQR) } 64 \text { (55- } \\
68)\end{array}$ & 53.2 & 28 & $\begin{array}{l}\mathrm{HR}=0.36 \\
(0.16-0.78)\end{array}$ & Mortality & ACEi/ARB & 7 \\
\hline $\begin{array}{l}\text { Li J. et al } \\
(2020)\end{array}$ & China & $\begin{array}{l}\text { Case- } \\
\text { control }\end{array}$ & 1178 & $\begin{array}{l}55.5 \text { years } \\
\text { (interquartile }\end{array}$ & $46.3 \%$ & 27 & $\begin{array}{l}1.11(0.72- \\
1.73)\end{array}$ & Severity & ACEi/ARB & 8 \\
\hline & & study & & $\begin{array}{l}\text { range, 38-67 } \\
\text { years) }\end{array}$ & & & $\begin{array}{l}1.23(0.75- \\
2.01) \\
\end{array}$ & Severity & ARB & \\
\hline
\end{tabular}




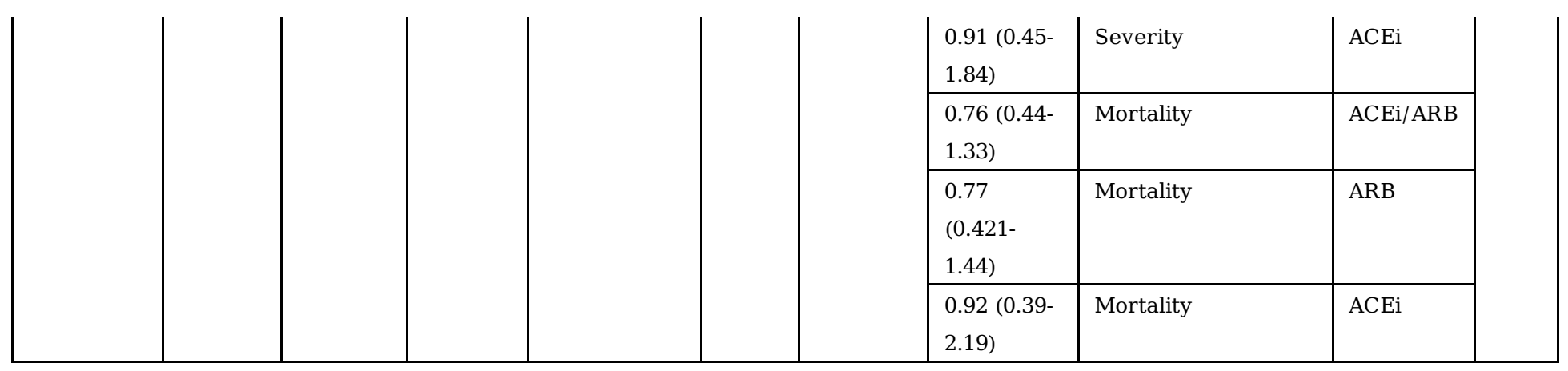

SD: standard deviation. CI: confidence interval. RAS: Renin-Angiotensin system. NOS: Newcastle-Ottawa Scale. CC: case control.

Table 2. Summary of subgroup analyses.

\begin{tabular}{|l|c|c|c|}
\hline Subgroup & Studies (n) & Adjusted OR (95\% CI) & P \\
\hline Mean age (years) & 4 & $0.68(0.27-1.76)$ & 0.429 \\
$<60$ & 9 & $0.72(0.42-1.23)$ & 0.232 \\
$\geq 60$ & 9 & $0.77(0.47-1.26)$ & 0.292 \\
\hline$\%$ male sex & 4 & $0.57(0.19-1.68)$ & 0.308 \\
$<55$ & 7 & $0.83(0.52-1.33)$ & 0.436 \\
$\geq 55$ & 6 & $0.74(0.35-1.57)$ & 0.430 \\
\hline Type of Renin-angiotensin system inhibitors (RAS) & & & \\
ARB & & & \\
ACEi & & & \\
\end{tabular}

\section{Figures}




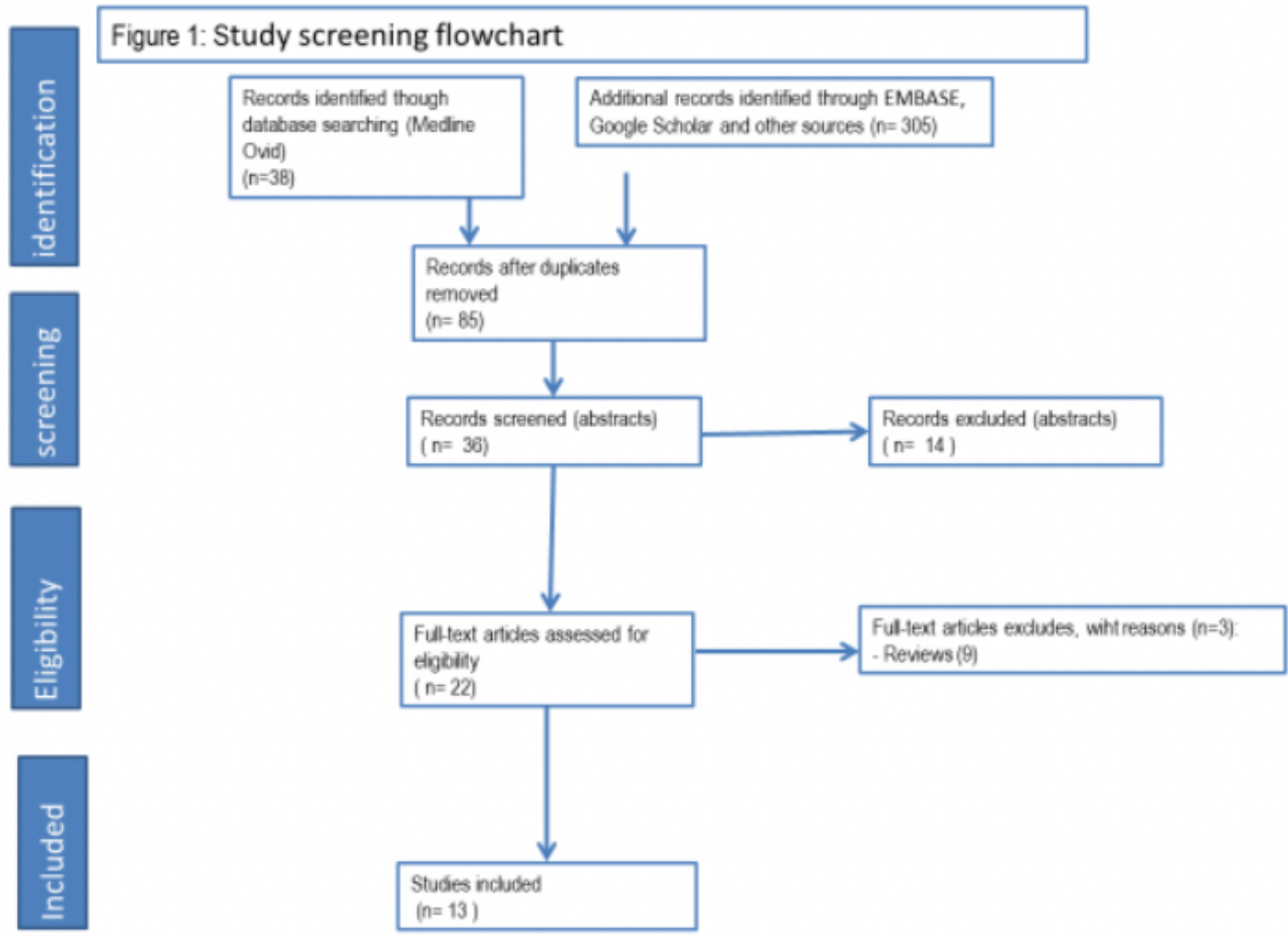

Figure 1

Flowchart of included studies. 
Study

ID

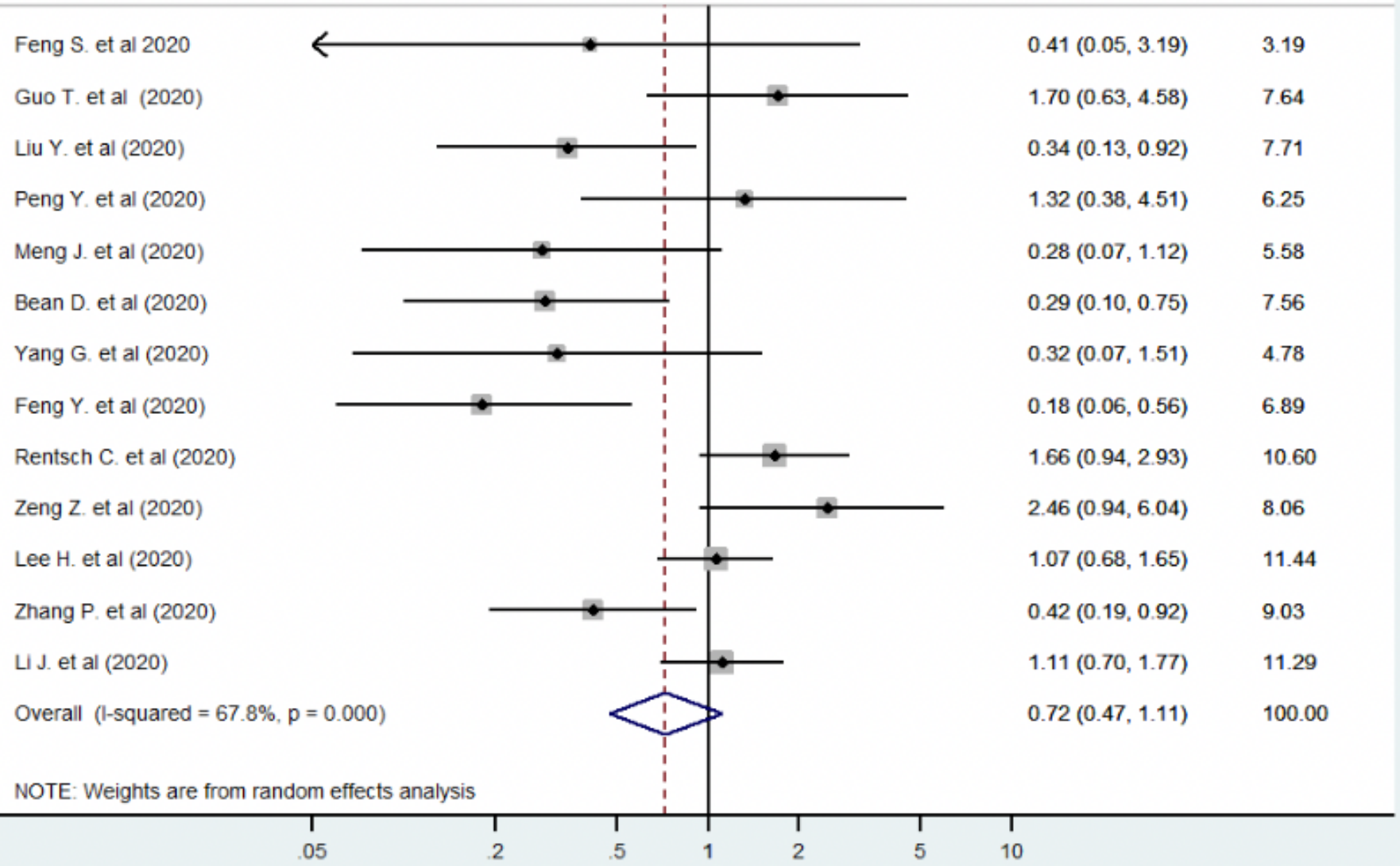

\section{Figure 2}

Forest plot of the meta-analysis of the association between ACEi or ARB use and SARS-CoV-2 infection severity or mortality. Analysis model: random effect. OD: Odd ratio. Cl: confidence interval.

\section{Supplementary Files}

This is a list of supplementary files associated with this preprint. Click to download.

- Supplementarydata.docx 